University of Montana

ScholarWorks at University of Montana

$12-2010$

\title{
Counterintuitive Effects of Large-Scale Predator Removal on a Midlatitude Rodent Community
}

John L. Maron

University of Montana - Missoula, john.maron@mso.umt.edu

Dean E. Pearson

Robert J. Fletcher Jr.

Follow this and additional works at: https://scholarworks.umt.edu/biosci_pubs

Part of the Biology Commons

Let us know how access to this document benefits you.

\section{Recommended Citation}

Maron, John L.; Pearson, Dean E.; and Fletcher, Robert J. Jr., "Counterintuitive Effects of Large-Scale Predator Removal on a Midlatitude Rodent Community" (2010). Biological Sciences Faculty Publications. 246.

https://scholarworks.umt.edu/biosci_pubs/246

This Article is brought to you for free and open access by the Biological Sciences at ScholarWorks at University of Montana. It has been accepted for inclusion in Biological Sciences Faculty Publications by an authorized administrator of ScholarWorks at University of Montana. For more information, please contact scholarworks@mso.umt.edu. 


\title{
Counterintuitive effects of large-scale predator removal on a midlatitude rodent community
}

\author{
John L. Maron, ${ }^{1,4}$ Dean E. Pearson, ${ }^{2}$ and Robert J. Fletcher, Jr. ${ }^{3}$ \\ ${ }^{1}$ Division of Biological Sciences, University of Montana, Missoula, Montana 59812 USA \\ ${ }^{2}$ Rocky Mountain Research Station, U.S. Forest Service, Missoula, Montana 59812 USA \\ ${ }^{3}$ Department of Wildlife Ecology and Conservation, P.O. Box 110430, University of Florida, Gainesville, Florida 32611 USA
}

\begin{abstract}
Historically, small mammals have been focal organisms for studying predatorprey dynamics, principally because of interest in explaining the drivers of the cyclical dynamics exhibited by northern vole, lemming, and hare populations. However, many small-mammal species occur at relatively low and fairly stable densities at temperate latitudes, and our understanding of how complex predator assemblages influence the abundance and dynamics of these species is surprisingly limited. In an intact grassland ecosystem in western Montana, USA, we examined the abundance and dynamics of Columbian ground squirrels (Spermophilus columbianus), deer mice (Peromyscus maniculatus), and montane voles (Microtus montanus) on 1-ha plots where we excluded mammalian and avian predators and ungulates, excluded ungulates alone, or allowed predators and ungulates full access. Our goal was to determine whether the relatively low population abundance and moderate population fluctuations of these rodents were due to population suppression by predators. Our predatorexclusion treatment was divided into two phases: a phase where we excluded all predators except weasels (Mustela spp.; 2002-2005), and a phase where all predators including weasels were excluded (2006-2009). Across the entire duration of the experiment, predator and/or ungulate exclusion had no effect on the abundance or overall dynamics of ground squirrels and deer mice. Ground squirrel survival (the only species abundant enough to accurately estimate survival) was also unaffected by our experimental treatments. Prior to weasel exclusion, predators also had no impacts on montane vole abundance or dynamics. However, after weasel exclusion, vole populations reached greater population peaks, and there was greater recruitment of young animals on predator-exclusion plots compared to plots open to predators during peak years. These results suggest that the impacts of predators cannot be generalized across all rodents in an assemblage. Furthermore, they suggest that specialist predators can play an important role in suppressing vole abundance even in lower-latitude vole populations that occur at relatively low densities.
\end{abstract}

Key words: Columbian ground squirrel; deer mouse; Microtus montanus; montane vole; Peromyscus maniculatus; population fluctuations; predation; predator-exclusion experiment; predator-prey dynamics; Spermophilus columbianus.

\section{INTRODUCTION}

Understanding the role of top predators in driving the abundance and dynamics of animal populations has had a long and venerable history in ecology (Elton 1924, Lack 1954, Hairston et al. 1960, Errington 1967). Elegant laboratory and field experiments as well as theoretical models have elucidated how various behavioral and ecological factors can generate interesting and complex dynamics between predators and their prey (Gause 1934, Huffaker 1958, Holling 1959). Yet in nature, determining how collections of predators influence the abundance of multispecies prey assemblages is logistically challenging. Nowhere has this challenge been better illustrated than on studies of small-mammal

Manuscript received 22 January 2010; revised 19 April 2010; accepted 26 April 2010. Corresponding Editor: D. W. Morris.

${ }^{4}$ E-mail: john.maron@mso.umt.edu dynamics. On the one hand, small mammals have been model organisms for the study of population dynamics. Many small-mammal species have short generation times with volatile dynamics that have been well characterized by long-term time series (e.g., MacLulich 1937, Keith 1990, Stenseth and Ims 1993, Boonstra et al. 1998). Such data have provided ample substrate on which to decompose the behavioral and ecological factors that might influence large and rhythmic changes in population abundance through time. On the other hand, research on small-mammal dynamics has generated a fair amount of controversy, as diverse research groups using different methodology and studying different species have often come to very disparate conclusions about the importance of various drivers of small-mammal dynamics.

Most of the research on small-mammal population dynamics has focused on high-latitude cyclic species, particularly voles, lemmings, and hares (Klemola et al. 
2003, Korpimäki et al. 2004, Sundell 2006). Here, a real emphasis has been to understand the role of specialist and generalist predators in driving population cycles (Gilg et al. 2003). Two broad approaches have primarily been used. The first approach has been to fit mechanistic models to underlying data, in order to determine the factors that may drive population change over various phases of population abundance (Hanski et al. 2001, Gilg et al. 2003, Turchin 2003). The second approach has involved manipulative experiments where predator abundance is reduced either through trapping or by physically excluding predators from plots and examining how this manipulation influences subsequent rodent dynamics (reviewed by Sundell 2006). Together these approaches have provided evidence that specialist predators can invoke time lags that cause cyclical fluctuations in numbers in northern vole populations (Norrdahl 1995, Korpimäki and Krebs 1996, Korpimäki and Norrdahl 1998, Hanski et al. 2001, Korpimäki et al. 2002, Norrdahl and Korpimäki 2002, Korpimäki et al. 2004, Korpimäki et al. 2005; but see Graham and Lambin 2002).

Yet, this body of work is also not without controversy. Correlative approaches to determining how extrinsic factors influence prey dynamics are problematic (Royama 1996). In particular, modeling results have been criticized because, even if data generated by a mechanistic model generally match empirically derived data, one can never be certain that the processes that are being modeled are the true determinants of patterns seen in complex field environments (Krebs 1995). Manipulative experiments have had their own problems, which have centered on (1) no or low replication; (2) small spatial scale; (3) confounding effects of exclosure fencing; or (4) the fact that in some cases only a subset of the predator assemblage is experimentally excluded, thereby leaving the possibility open for strong compensatory responses by predators not excluded (summarized by Sundell 2006). Beyond methodological concerns, research has been so heavily focused on understanding the determinants of dynamics of cyclic high-latitude small-mammal populations that other equally important questions have been relatively unaddressed.

Most rodent species occur at mid- or lower latitudes and exhibit relatively low and stable numbers or fluctuate but do not cycle. What role might predators play in limiting the abundance of these species? Several authors have suggested that, at least for some noncyclic vole populations, their low levels of abundance might result from predation by generalists (Erlinge 1987, Hanski et al. 1991, Korpimäki et al. 2005). Nonetheless, data to support this claim are limited, as few studies have experimentally determined the general importance of predators or evaluated the influence of predator identity in limiting the abundance of noncyclic species that occur at midlatitudes (but see Reid et al. 1995, Meserve et al. 1996, 2003). In some ways, this state of affairs is unsurprising. In many temperate systems, the predator assemblage has been so dramatically altered that it is no longer possible to determine how predators may have affected their prey. For example, in much of North America, carnivore declines and disappearances from systems have been substantial (Soule et al. 2003). This has prompted some to argue that the lack of a clear signal for strong top-down forcing noted in a variety of studies is in part due to anthropogenic-driven reductions of vertebrate predators in many ecosystems (Duffy 2002). Additionally, not only are predator assemblages disrupted in many systems, but so too are the plant communities as a result of domestic grazing or through exotic plant invasion. Gross changes in plant-community composition and productivity can alter rodent populations (Rosenstock 1996, Keesing 1998, Steen et al. 2005); subsidized prey populations can also potentially alter predator impacts on prey dynamics (Leroux and Loreau 2008). Finally, the logistical challenges associated with experimentally determining how speciesrich predator assemblages influence the population dynamics of co-occurring rodent species are not inconsequential (Sundell 2006).

Here we report how a diverse predator assemblage influenced the abundance and dynamics of three cooccurring small mammals that inhabit native grasslands of western Montana, USA. We experimentally excluded avian and mammalian predators and ungulates, ungulates alone, or none of these animals from 1-ha plots in order to examine impacts on ground squirrel (Spermophilus columbianus), deer mouse (Peromyscus maniculatus), and montane vole (Microtus montanus) abundance. The exclusion of predators was performed in two phases. During the first phase, we excluded all mammalian and avian predators (mostly generalist predators) except weasels (vole specialists); thereafter we excluded all predators. This allowed us to evaluate the influence of weasels (Mustela spp.), which have been documented to be particularly important specialist predators at higher latitudes, relative to the overall predator guild. By quantifying predator impacts over relatively large spatial (1 ha) and temporal (seven years) scales, our intent was to circumvent some of the perceived limitations with previous experiments on predatorsmall-mammal dynamics (Sundell 2006). Our overall goal was to determine the role of predation and predator identity in affecting the abundance of midlatitude small mammals that occur at relatively modest densities.

\section{Methods \\ Study system}

Research took place in semiarid grasslands within the Blackfoot Valley in western Montana $\left(47^{\circ} 01^{\prime} 13.11^{\prime \prime} \mathrm{N}\right.$, $113^{\circ} 07^{\prime} 59.21^{\prime \prime} \mathrm{W}$ ). Precipitation averages $32 \mathrm{~cm} / \mathrm{yr}$, and mean summer (June-August) monthly temperature ranges are $12-15^{\circ} \mathrm{C}$. Due to its proximity to the Bob Marshall Wilderness and conservation-oriented management of public and private lands, the Blackfoot Valley supports one of the few remaining native 
grassland ecosystems in North America containing all the mammalian and avian predators that have historically occurred there (Appendix A). The plant community is dominated by the native bunchgrasses Festuca scabrella and $F$. idahoensis and a diversity of native forbs. Threetip sagebrush (Artemesia tridentata) is the dominant woody shrub, although its abundance varies greatly across our sites. Four species of native ungulates occur in our system: elk (Cervus elaphus), white-tailed deer (Odocoileus virginianus), mule deer (O. hemionus), and moose (Alces alces). Although up to 1400 elk winter in the Blackfoot Valley, in summer most elk and mule deer move to higher elevations. Small-mammal consumers include deer mice, montane voles, Columbian ground squirrels, yellow-pine chipmunks (Tamias amoenus), mountain cottontails (Sylvilagus nuttallii), montane shrews (Sorex monticolus), and northern pocket gophers (Thomomys talpoides). We focused on deer mice, montane voles, and Columbian ground squirrels since these species were the only ones that were consistently trapped at each of our sites. Other species only occurred sporadically (and we saw no evidence of predator impacts on the abundance of these uncommon species).

\section{Experimental design: predator and/or ungulate exclusion}

We established our experiment at four replicate sites across the Blackfoot Valley (average distance between sites $>23 \mathrm{~km}$, minimum distance $=7.5 \mathrm{~km}$ ). Three sites were established in September 2002 and a fourth was added in September 2005. At each site, we identified three $100 \times 100 \mathrm{~m}$ plots that had similar vegetation characteristics and were separated from each other by at least $100 \mathrm{~m}$. We randomly assigned each of the following three treatments to plots at each site: predator and ungulate exclosure (hereafter predator exclosure), ungulate exclosure, and control. Although the primary objective of the study was to examine predator effects on small mammals, large predators could not be excluded without also excluding ungulates, so this necessitated a treatment to separate ungulate from predator effects.

Predator-exclosure plots were surrounded by game fencing (Bekaert Industries, Kortrijk, Belgium) topped with two strands of high-tension wire (total fence height $=2.6 \mathrm{~m}$ ). Raptors were excluded by overhead parallel strands of $0.025 \mathrm{~mm}$ diameter stainless steel wire, strung tight and spaced $20 \mathrm{~cm}$ apart. From September 2002August 2005, we excluded all predators except weasels from predator-exclusion plots. In September 2005 we retrofitted predator-exclusion fences to exclude both short- and long-tailed weasels (Mustela erminea and Mustela frenata, respectively; hereafter "weasels" for simplicity; see Appendix B for details of fence construction). Ungulate exclosures consisted of a $2.4 \mathrm{~m}$ tall $10-$ stranded barbed-wire fence (strand spacing $=0.24 \mathrm{~m}$ ) with no overhead wires. This fencing excluded ungulates but allowed predators (except bears) to pass freely. Control plots were unfenced but had $2 \mathrm{~m}$ tall fence posts approximately every $20 \mathrm{~m}$ along the perimeter to control for raptor perch sites created by fence posts around the other plots.

\section{Small-mammal population sampling}

We trapped small mammals in spring (mid-May through the first week in June), midsummer (mid-July), and late summer (mid-August) on $10 \times 10 \mathrm{~m}$ permanently marked grids (10-m spacing) located in the center of each 1-ha plot. We placed one Sherman live trap (7.6 $\times 8.9 \times 22.9 \mathrm{~cm}$; H. B. Sherman Traps, Tallahassee, Florida, USA) at each station (100 traps total) to target Peromyscus maniculatus and Microtus montanus and set a Tomahawk trap $(17.8 \times 17.8 \times 50.8 \mathrm{~cm}$; model 605 , Tomahawk Live Trap, Tomahawk, Wisconsin, USA) at each of 16 stations across the grid (20-m spacing) to target Spermophilus columbianus (see Appendix C for details of trapping methodology).

\section{Snow tracking}

We snow-tracked plots in winter to verify that treatments were effective and to quantify mammal activity. Snow tracking occurred two to four days following snow events whenever conditions allowed. All plots within a site were tracked on the same day. Ten $10 \mathrm{~m}$ wide permanent parallel belt transects were run across each plot and divided into 1010 -m segments (10 $10 \times 10 \mathrm{~m}$ cells per belt transect, 100 cells total per plot). The presence and identity of fresh tracks were scored for all cells.

\section{Analyses}

We estimated species abundance and associated variance for each five-day trapping interval for each plot by considering the population closed within each season (Otis et al. 1978) using Program MARK (White and Burnham 1999). Population abundance was estimated using a two-point mixture model (Pledger 2000), which incorporates heterogeneity into capture probabilities. For these models, we also considered additive effects of year, treatment, and season on capture probabilities, selecting the most parsimonious model structure using Akaike's Information Criterion, adjusted for sample size $\left(\mathrm{AIC}_{\mathrm{c}}\right)$.

With these estimates, we analyzed variation in abundance and survival using generalized linear mixed models for count data (abundance estimates), by assuming a Poisson error distribution and a log link function. We considered treatment (control, generalist predator exclosure [predator-exclusion plots from 2002 2005], generalist predators + weasel exclosure [predatorexclusion plots from 2006-2009], and ungulate exclosure) as fixed, site as a random blocking effect, and time as a repeated measure using PROC GLIMMIX (SAS 2008). Because the two types of predator exclosures only occurred in either 2002-2005 or 2006-2009, we initially tested whether abundance differed on controls and ungulate exclosures between the 2002-2005 and 2006- 
2009 time periods, but found no evidence for temporal differences for any species $(P \geq 0.11$ in all cases). In August 2009, immediately after we finished rodent trapping, we detected definitive evidence (weasel tracks on track plates placed inside of the predator-exclosure plot) that a weasel had breached the predator-exclusion fence at one of our sites. This coincided with a dramatic drop in vole abundance (from 21 individuals/ha in May to 3 individuals/ha in August) on this plot. Since we had unambiguous evidence for weasel entry during this one trapping period at this one site, we coded data from this plot and trapping period as "generalist predator exclosure" rather than "generalist predator + weasel exclosure." We initially contrasted different models of the variance-covariance matrix describing the repeated measure and chose descriptions that minimized overdispersion in the models. Degrees of freedom were adjusted using the Kenward-Rogers method, which is recommended for repeated-measures analyses (Littell et al. 2006:188). Importantly, we decomposed the treatment effects into three orthogonal contrasts for interpreting the effects of predator removals on prey. First, we contrasted estimates on controls and ungulate exclosures. If there was no evidence for differences between these control and ungulate exclosures, we then contrasted the estimates from generalist predator exclosures and generalist predator + weasel exclosures to the average of ungulate exclosures and controls.

We also estimated apparent monthly survival rates for S. columbianus using a multistate, robust design model. We did not model apparent survival for the other species because recaptures for P. maniculatus and M. montanus were too limited for reliable estimates (only $2.6 \%$ and $0.3 \%$ of individuals, respectively, were recaptured more than once across seasons). Because there was a small portion of $S$. columbianus that moved among treatment plots, we used a multistate formulation where treatments were different potential states that individuals could occupy. To obtain estimates, we used a step-down approach, where we first modeled capture probability, and then modeled apparent survival, given the most parsimonious model for capture probability (Lebreton et al. 1992). For capture probability and survival, we began with a fully specified, time $\times$ treatment parameterization and contrasted this with all reduced combinations using $\mathrm{AIC}_{\mathrm{c}}$. For movement, we only considered a constant parameterization, because movement events were very infrequent.

Since montane voles were the only species that responded to predator exclusion, we used the same linear model structure used to test for treatment effects on vole abundance to examine how our experimental treatments influenced vole sex ratios, juvenile recruitment, reproductive activity in females, and body mass. We calculated sex ratios as the proportion of adult and subadult males, such that values $>0.5$ indicated a greater ratio of males to females captured. The analysis for sex ratios assumed a binomial error distribution for this variable. Juvenile recruitment was defined as the ratio of juveniles to adult and subadult females. Female reproductive activity was defined as the proportion of breeding (defined as having enlarged mammae) adult and subadult females over all adult and subadult females. Body mass was evaluated only for adult males using mass at first capture (Pearson et al. 2003). Female body mass can be quite variable due to pregnancy that often cannot be determined visually.

We analyzed snow-tracking data by comparing the number of cells in each survey with tracks of weasels, large predators (primarily coyotes and badgers), ungulates, and small mammals (primarily deer mice) across treatments. We considered treatment as a fixed effect, site as a random blocking effect, and multiple track surveys as a repeated measure using PROC MIXED (SAS 2008). For weasel tracks, this analysis was conducted separately before and after weasel exclusion. All analyses were followed with post hoc Tukey-Kramer tests.

To test for a fence effect (sensu Ostfeld 1994), we compared the distribution of vole mass between predator-exclusion and predator-open plots (i.e., controls and ungulate exclosures). A fence effect would be characterized by a greater number of heavier animals being present on predator-exclusion plots compared to plots open to predators, since predator-exclusion plots do not allow emigration of animals $>22 \mathrm{~g}$. We used an independent samples Kolmogorov-Smirnov test to compare mass distributions between treatments for the two peak years 2006 and 2009 when voles responded to the predator treatment. The ungulate and control treatments were combined, and data were pooled for 2006 and 2009, since distributions between peak years were similar.

\section{Results}

Ungulate-exclusion fences were generally effective; we only had two instances of animals breaching fences. These break-ins occurred in winter and were discovered quickly, and the fences were immediately repaired. Exclusion efficacy was reflected in snow-tracking data showing that ungulate activity was lower on exclusion plots compared to controls (pooled ungulate exclusion $=$ $0.8 \pm 3.2$, predator exclusion $=1.6 \pm 3.2$, control $=16.9$ \pm 3.2 [mean $\pm \mathrm{SE}$ ] $F_{2,73}=27.64, P<0.001$ ). Large predators were entirely excluded from the generalist predator- and generalist predator + weasel-exclusion plots $\left(F_{2,85}=9.09, P<0.001\right)$. There was a trend toward reduced predator activity on the ungulate-exclusion plots relative to controls, but this was not significant (Tukey-Kramer $t_{85}=1.70, P=0.21$ ). Before we retrofitted predator-exclusion plots to keep out weasels, weasel tracks did not differ between generalist predatorexclusion and other plots $\left(F_{2,21}=0.34, P=0.71\right)$. Across all years we had signs of weasel activity at all sites, although from snow tracking, there were some years where some sites had no weasel tracks on particular 
plots. After plots were retrofitted to remove weasels, weasel activity was greatly suppressed on predatorexclusion plots. Although we did detect weasel activity in winter on two predator-exclusion plots after retrofitting exclosures, they were isolated instances that occurred soon after fences were retrofitted (generalist predator + weasel $=0.8 \pm 0.9$, control $=2.0 \pm 0.9$, ungulate $=3.8 \pm 0.9$ [mean $\pm \mathrm{SE}] ; F_{2,66}=3.42, P=$ 0.039 ). After these break-ins, we identified and fortified sections of the predator-exclusion fence where weasels had entered. Small-mammal tracks, which were mostly deer mice, did not differ across any treatments $\left(F_{2,62}=\right.$ $0.27 ; P=0.76$ ).

Overall, we captured 928 Peromyscus maniculatus and 636 Microtus montanus from 2002-2009, and 646 Spermophilus columbianus from 2004-2009. All plots were occupied by all species on several occasions throughout the experiment, with the pooled percentage of occupancy of plots per time period being $86.5 \%$ for $P$. maniculatus, $87.6 \%$ for S. columbianus, and $52.8 \%$ for $M$. montanus. We found no substantive effects of treatments on the abundance of either $S$. columbianus or $P$. maniculatus across the duration of the experiment (Figs. 1, 2; Appendix D). However, M. montanus exhibited increases in abundance on predator-exclosure plots, but only following weasel exclusion from 2006-2009 $\left(F_{1,35.49}\right.$ $=13.12, P=0.0009$; Figs. 1, 2; Appendix D). For $M$. montanus, we did not include estimates from 2002 because estimated capture probabilities in this year were extremely low (capture probability $=0.03$ ), limiting inference in variation in abundance for 2002 (but including these estimates into general linear mixed models did not change conclusions).

The best model to explain apparent survival rates of S. columbianus included an additive effect of treatment and time (Appendix E). Based on estimates from this model and a model that only included a treatment effect, the treatment effect was driven by differences between controls and ungulate exclosures, rather than generalist predator or general predator + weasel exclosures (Appendix E). The time effect suggested that monthly survival was higher from midsummer to spring than from spring to midsummer. We note, however, that the time between midsummer to spring included, on average 10.5 months, whereas the time between spring to midsummer included approximately 1.6 months. Consequently, the differences in absolute survival rates $(S)$ across these seasons were less extreme than those shown in Appendix E, with overall survival rates being lower from midsummer to spring $(S=0.58)$ than spring to midsummer $(S=0.65)$.

Mass distributions for $M$. montanus differed between predator and nonpredator treatments (ungulate exclusion + control vs. predator exclusion for pooled plots; Kolmogorov-Smirnov test: $D=1.38, P=0.045)$, but this was due to proportionally more young animals $(<22 \mathrm{~g})$ on the predator-exclusion plots compared to plots open to predators. Since young animals were not restricted by

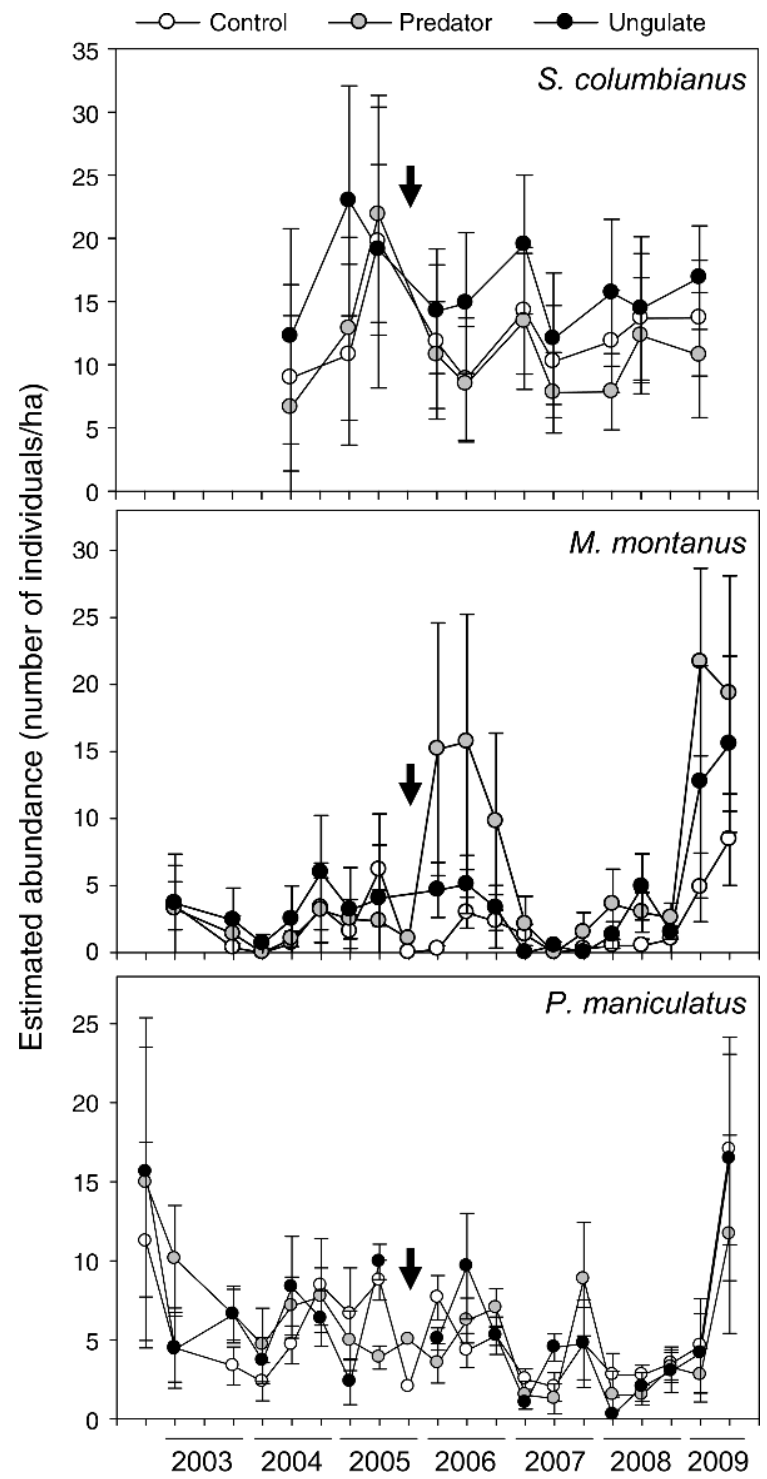

FIG. 1. Abundance estimates (individuals/ha; mean $\pm \mathrm{SE}$ ) from a two-point mixture model over time for Spermophilus columbianus, Microtus montanus, and Peromyscus maniculatus in controls, predator exclosures, and ungulate exclosures during 2002-2009 in an intact grassland ecosystem in western Montana, USA. Arrows denote when the predator-exclusion plots were retrofitted to exclude weasels.

the fence, we retested the distributions using data only from animals $>22 \mathrm{~g}$, which were those potentially restricted by the weasel fence. This analysis revealed no difference in mass distributions among treatments (Kolmogorov-Smirnov test: $D=0.35, P=1.000$ ).

Across all trapping periods there was no effect of treatments on the mass of adult male voles $\left(F_{3,40.8}=\right.$ $0.05, P=0.98$; Fig. 3$)$ or vole sex ratios $\left(F_{3,58.2}=0.33, P\right.$ $=0.81$; Fig. 3). However, juvenile recruitment into the population and female reproductive activity were significantly greater on plots from which predators were excluded compared to controls, but only after weasels 

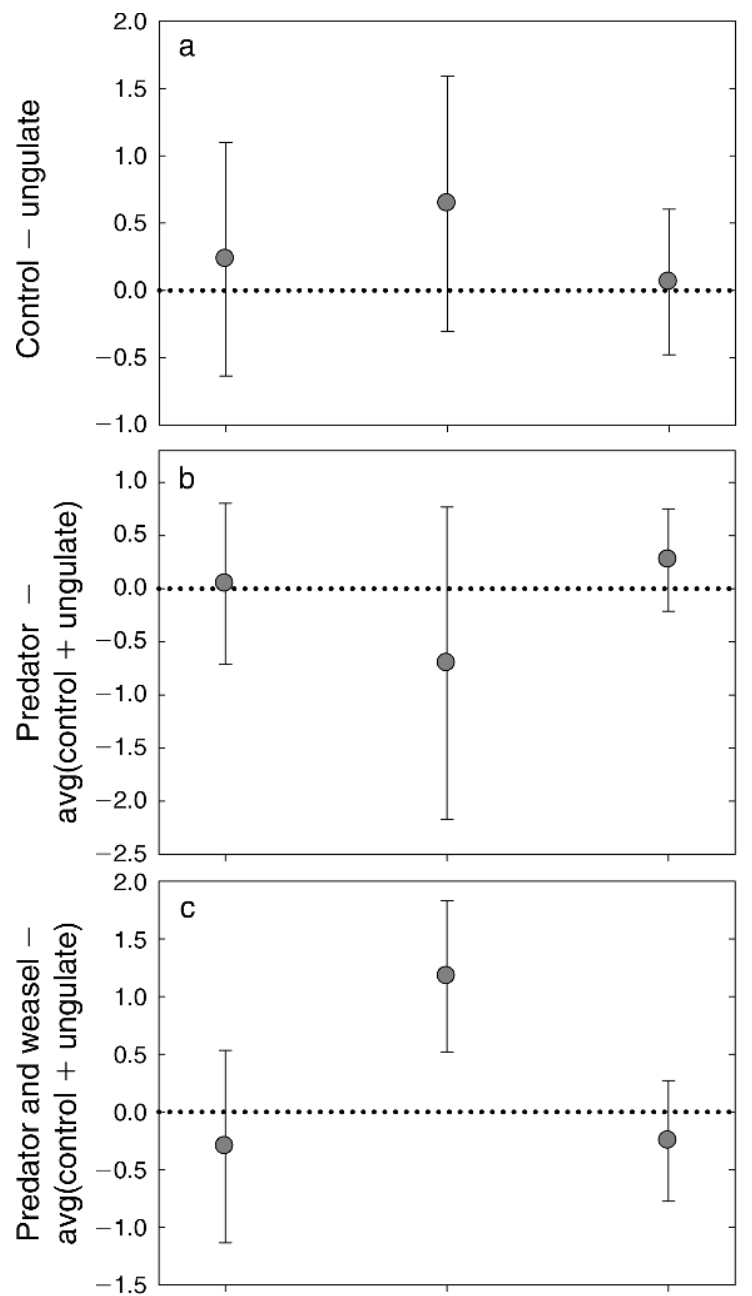

S. columbianus $M$. montanus $P$. maniculatus

FIG. 2. Contrasts (beta estimates with $95 \%$ CI) taken from general linear mixed models for abundance estimates of Spermophilus columbianus, Microtus montanus, and Peromyscus maniculatus for (a) differences between controls and ungulate exclosures, (b) generalist predator exclosures (pre-2006) compared with the average of controls and ungulate exclosures, and (c) generalist predator and weasel exclosures (post-2006) compared with the average of controls and ungulate exclosures. Confidence intervals that do not overlap with zero denote significant contrasts.

were excluded (contrast for recruitment: $F_{1,39}=10.77, P$ $=0.002$; reproductive activity: $F_{1,81}=7.16, P=0.009$; Fig. 3).

\section{DisCUSSION}

Our seven-year predator-exclusion experiment revealed that a diverse group of vertebrate predators have remarkably little influence on ground squirrel and deer mouse abundance and dynamics. However, specialist weasels had strong but temporally varying impacts on montane vole populations. Exclusion of all avian and mammalian predators except weasels (from 2002-2005) had minimal effects on vole numbers or dynamics. But after excluding weasels along with all other predators (from 2006 onward), voles attained greater population peaks and higher juvenile recruitment rates during peak years compared to voles on plots that were exposed to predators.

Anecdotal observations support these results. In spring 2009 during a peak in vole numbers, there were 21 animals/ha on one of our predator-exclusion plots compared to 2 animals/ha on the paired control. This predator-exclusion effect grew even stronger over the season at other sites, but on this plot the population declined from 21 to 3 animals. In August, track plates inside the predator-exclosure plot at this one site revealed a weasel had entered (although we accounted for this in analysis of treatment effects). Heavy weasel predation has been reported in other montane vole populations (Fitzgerald 1977).

The lower amplitude population fluctuations and/or lower population abundance of small mammals characteristic of lower latitude populations are often attributed to the impacts of generalist predators (Erlinge 1987, Korpimäki et al. 2005; but see Boonstra and Krebs 2006). For instance, in southern Fennoscandia, generalist predators are thought to stabilize volatile smallmammal population dynamics, whereas specialists in the north are thought to drive unstable cyclical dynamics (Norrdahl 1995, Korpimäki and Krebs 1996, Korpimäki and Norrdahl 1998, Klemola et al. 2000, Hanski et al. 2001, Norrdahl et al. 2002, Korpimäki et al. 2004). However, few studies have experimentally examined the relative role of specialist vs. generalist predators at the same midlatitude sites. Our results are counterintuitive in that they suggest that specialists suppress population cycles as opposed to driving them, and that generalists have few impacts. Prior to weasel exclosure, when only generalist vole predators were manipulated, voles showed only low population densities and no peaks for four years (Fig. 1). After specialist weasels were excluded, we observed two peaks in vole abundance. The first was not reflected at all on the predator-access plots. During the second peak, increases occurred on the predator-access plots, but were weaker than on plots where predators were excluded. We speculate that the rise in vole abundance on plots open to predators during the summer of 2009 may have been due to the fact that this was an extremely productive year for grasses at our sites. Associated increases in invertebrates and seed production could explain why deer mouse populations also increased during summer 2009.

The difference in vole abundance on predator-free vs. predator-access plots appears to be caused in part by a difference in the reproductive output of females on these different plots. We observed higher juvenile recruitment rates per female and a greater proportion of reproductively active female voles on predator-free plots compared to plots open to predators. Korpimäki et al. (1994) proposed that high predation risk during the low phase of vole cycles in Fennoscandia causes bank voles 

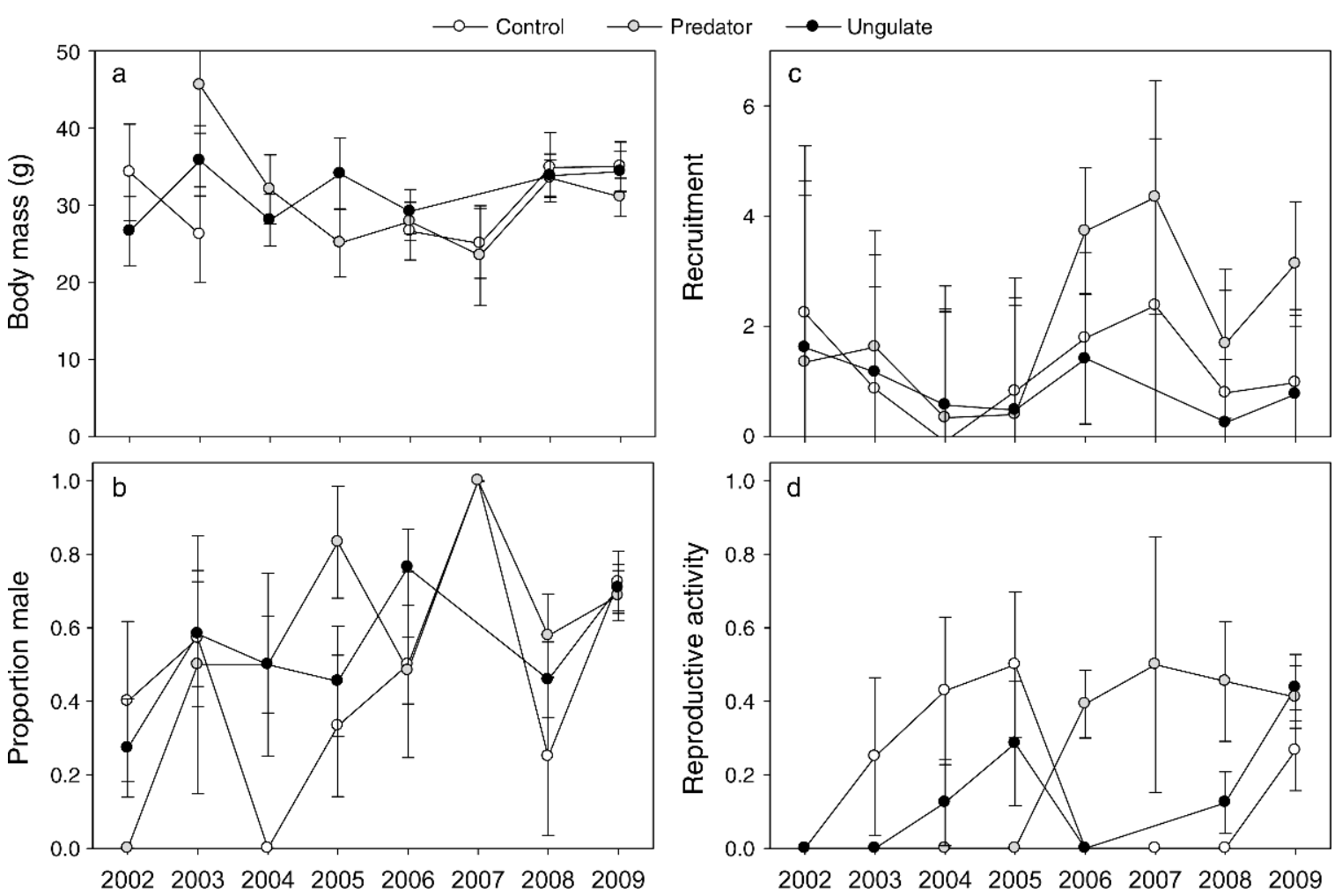

FIG. 3. Annual variation in (a) body mass, (b) the proportion male, (c) juvenile recruitment (ratio of juveniles to adult and subadult females), and (d) reproductive activity (the proportion of breeding adult and subadult females to all adult and subadult females) of Microtus montanus in controls, predator exclosures, and ungulate exclosures. Values are expressed as mean \pm SE. Note that prior to 2006, predator exclosures did not exclude weasels.

to reduce their reproduction. This suggests weasels could impact voles not only through direct mortality, but also through nonconsumptive behavioral effects or a "fear factor" that alters their growth rates (Preisser et al. 2005). Our data are particularly interesting in this regard in that during the first population peak (2006), no females showed signs of reproductive activity on predator-access plots, while a substantial percentage of females $(39 \%)$ bred on predator-free plots. In contrast, during the second peak (2009), differences in reproductive activity between female voles in plots with and without predator access diminished (35\% vs. $41 \%$, respectively). This suggests that weasels had both strong density and behavioral impacts on voles during the first peak, but only density effects during the second peak. Such an outcome could result from differences in resource availability interacting with predator effects (e.g., Denno et al. 2003). This interpretation is bolstered by the fact that vegetation biomass in our system was extraordinarily high during the second peak year in 2009. High resource levels during this year may have overridden the negative nonconsumptive predator effects on vole reproduction on predator-access plots.

Experimentally excluding weasels required using a mesh size of fencing that limits the passage of voles $>22$ $\mathrm{g}$ through the fence (J. Maron and D. Pearson, unpublished data). This creates the possibility that increases in voles on predator-free plots could have been caused by a "fence effect" as opposed to predator suppression. However, if the buildup in vole numbers on predator-exclusion plots was due to a fence effect, during population peaks we would expect that these plots would contain a greater fraction of heavier animals (those $>22 \mathrm{~g}$ ) compared to plots without predatorexclusion fencing. This was not the case.

In contrast to our results for voles, specialist predators had little impact on deer mouse and ground squirrel populations. Previous work has suggested that badgers specialize on preying on ground-nesting sciurids (Murie 1992, Michener 2004), and badgers were certainly active at our sites. We recorded badger tracks on plots open to predators in winter, and we frequently saw badgers in summer and even saw evidence of badger predation on ground squirrels. However, their exclusion (along with all other avian and mammalian predators) had insubstantial impacts on ground squirrel numbers or survival. Generalist predators such as coyotes are common, and generalist hawks and owls are certainly present (Appendix A), although not at high densities. Yet these species also had little impact on squirrel and deer mouse populations. In contrast, in one of the few other long-term and larger-scale predator-exclusion 
experiments where the entire predator assemblage was manipulated, Meserve et al. (1996) found that generalist predators reduced the survival and abundance of some rodent species (although not others).

In systems that are strongly driven by pulses of resources, bottom-up population limitation by food can be more important than predators in driving rodent abundance (Previtali et al. 2009). Grassland productivity in western Montana does vary across years (2009 was, for example, particularly productive) but there are not the extreme resource pulses that characterize systems with dominant masting species such as oaks (Wolff 1996, Clotfelter et al. 2007) or El Niño-driven pulses in vegetation (Ernest et al. 2000, Previtali et al. 2009). However, previous research indicates that ground squirrel and deer mouse populations in grasslands of the intermountain west may be resource limited. Dobson and Oli (2001) found that experimental food addition significantly increased the population growth rate of Columbian ground squirrels in southern Canada. Other ground squirrel species have also been shown to be at least partially food limited (Hubbs and Boonstra 1997). Deer mouse populations in western Montana similarly appear to be food limited. Populations subsidized by insect biocontrol agents in winter are two to three times larger than populations not exposed to this subsidy (Ortega et al. 2004, Pearson and Callaway 2006). While food resources and predation might interact in important ways to affect prey abundance (Krebs et al. 1995, Byrom et al. 2000, Denno et al. 2003), our results for ground squirrels and deer mice show that generalist or specialist predators, in isolation, are not important controlling influences on these species.

Perhaps the most intriguing result we found was that by excluding specialist weasels, we could experimentally induce volatile dynamics within montane vole populations that were limited or weak in the presence of this predator. In other words, our results suggest that both the abundance and dynamics of prey can be substantially altered by a single predator species. This result is interesting because it seems counter to what has been found in Fennoscandia. For example, Korpimäki and Norrdahl (1998) and Korpimäki et al. (2002) found that predator exclusion both increased peak vole numbers and reduced the magnitude of the crash phase. Alternatively, others have found that vole populations crash even when predators are removed, but that these crashes are due to starvation of animals after populations reach extremely high numbers (Klemola et al. 2000). We did not see obvious signs of starvation in our vole populations, nor did we see evidence that voles dramatically outstripped their food resources. It seems likely that the declines in population size we saw in the absence of predators were due to intrinsic factors, such as reductions in reproduction at high density, as have been implicated in vole declines in other populations (Krebs et al. 2007). Moreover, since we found that many abundant generalist predators had virtually no impacts on the abundance or dynamics of the rest of the smallmammal community, it appears that predator impacts cannot be easily generalized to the entire small-mammal community. Our preliminary data suggest that consumer impacts on plants similarly do not generalize to the entire consumer community. That is, deer mice and ground squirrels, those species not controlled by predators, appear to have strong impacts on plant abundance (Bricker et al. 2010; J. Maron and D. Pearson, unpublished data), whereas vole populations, even in the absence of predators, never reach densities high enough to be highly damaging to vegetation ( $\mathrm{J}$. Maron and D. Pearson, unpublished data). Thus we predict very limited long-term indirect effects of predators on plant productivity and abundance in our system. It may be that our system is somewhat typical of complex and species-rich communities, where no one apex predator plays a keystone role.

\section{ACKNOWLEDGMENTS}

We thank the Montana Fish, Wildlife and Parks and the U.S. Fish and Wildlife Service for allowing us to conduct experiments on their protected sites. We greatly appreciate the stellar field help from Cedar Brant, Mary Bricker, Jessica Clark, Mary Goldman, Winslow Hansen, Chris Henderson, Lindsey Holm, Christen Kiser, Adam Leiberg, David Lowry, Lorna McIntyre, Elliott Parsons, Ali Pons, Anna Semple, and Matt Wegner. Two anonymous referees provided extremely helpful comments that served to sharpen the manuscript. This project was partially supported by grants to J. Maron and D. E. Pearson from the National Research Initiative of the USDA Cooperative State Research, Education and Extension Service (grant number 2005-35101-16040), and grants to J. Maron from McIntire-Stennis and the U.S. Bureau of Land Management.

\section{Literature Cited}

Boonstra, R., and C. J. Krebs. 2006. Population limitation of the Northern red-backed vole in boreal forests of northern Canada. Journal of Animal Ecology 75:1269-1284.

Boonstra, R., C. J. Krebs, and N. C. Stenseth. 1998. Population cycles in small mammals: the problem of explaining the low phase. Ecology 79:1479-1488.

Bricker, M., D. Pearson, and J. L. Maron. 2010. Small mammal seed predation limits the recruitment and abundance of two perennial grassland forbs. Ecology 91:85-92.

Byrom, A. E., T. J. Karels, C. J. Krebs, and R. Boonstra. 2000. Experimental manipulation of predation and food supply of arctic ground squirrels in the boreal forest. Canadian Journal of Zoology 78:1309-1319.

Clotfelter, E. D., A. B. Pedersen, J. A. Cranford, N. Ram, E. A. Snajdr, V. Nolan, Jr., and E. D. Ketterson. 2007. Acorn mast drives long-term dynamics of rodent and songbird populations. Oecologia 154:493-503.

Denno, R. F., C. Gratton, H. Dobel, and D. L. Finke. 2003. Predation risk affects relative strength of top-down and bottom-up impacts on insect herbivores. Ecology 84:10321044.

Dobson, F. S., and M. K. Oli. 2001. The demographic basis of population regulation in Columbian ground squirrels. American Naturalist 158:236-247.

Duffy, J. E. 2002. Biodiversity and ecosystem function: the consumer connection. Oikos 99:201-219.

Elton, C. S. 1924. Periodic fluctuations in the numbers of animals: their causes and effects. British Journal of Experimental Biology 2:119-163. 
Erlinge, S. 1987. Predation and noncyclicity in a microtine population in southern Sweden. Oikos 50:347-352.

Ernest, S. K. M., J. H. Brown, and R. R. Parmenter. 2000. Rodents, plants and precipitation: spatial and temporal dynamics of consumers and resources. Oikos 88:470-482.

Errington, P. L. 1967. Of predation and life. Iowa State University Press, Ames, Iowa, USA.

Fitzgerald, B. M. 1977. Weasel predation on a cyclic population of the montane vole (Microtus montanus) in California. Journal of Animal Ecology 46:367-397.

Gause, G. F. 1934. The struggle for existence. Hafner, New York, New York, USA.

Gilg, O., I. Hanski, and B. Sittler. 2003. Cyclic dynamics in a simple vertebrate predator-prey community. Science 302: 866-868.

Graham, I. M., and X. Lambin. 2002. The impact of weasel predation on cyclic field-vole survival: the specialist predator hypothesis contradicted. Journal of Animal Ecology 71:946956.

Hairston, N. G., F. E. Smith, and L. B. Slobodkin. 1960. Community structure, population control, and competition. American Naturalist 94:421-425.

Hanski, I., L. Hansson, and H. Henttonen. 1991. Specialist predators, generalist predators, and the microtine rodent cycle. Journal of Animal Ecology 60:353-367.

Hanski, I., H. Henttonen, E. Korpimäki, L. Oksanen, and P. Turchin. 2001. Small-rodent dynamics and predation. Ecology 82:1501-1520.

Holling, C. S. 1959. The components of predation as revealed by a study of small mammal predation of the European pine sawfly. Canadian Entomologist 91:293-320.

Hubbs, A. H., and R. Boonstra. 1997. Population limitation in arctic ground squirrels: effects of food and predation. Journal of Animal Ecology 66:527-541.

Huffaker, C. B. 1958. Experimental studies on predation: dispersion factors and predator-prey oscillations. Hilgardia 27:343-383.

Keesing, F. 1998. Impacts of ungulates on the demography and diversity of small mammals in central Kenya. Oecologia 116: 381-389.

Keith, L. B. 1990. Dynamics of snowshoe hare populations. Pages 119-195 in H. N. Genoways, editor. Current mammalogy. Plenum Press, New York, New York, USA.

Klemola, T., M. Koivula, E. Korpimäki, and K. Norrdahl. 2000. Experimental tests of predation and food hypotheses for population cycles of voles. Proceedings of the Royal Society B 267:352-356.

Klemola, T., T. Pettersen, and N. C. Stenseth. 2003. Trophic interactions in population cycles of voles and lemmings: a model-based synthesis. Advances in Ecological Research 33: $75-160$.

Korpimäki, E., P. R. Brown, J. Jacob, and R. P. Pech. 2004. The puzzles of population cycles and outbreaks of small mammals solved? BioScience 54:1071-1079.

Korpimäki, E., and C. J. Krebs. 1996. Predation and population cycles of small mammals. BioScience 45:754-764.

Korpimäki, E., and K. Norrdahl. 1998. Experimental reduction of predators reverses the crash phase of small-rodent cycles. Ecology 79:2448-2455.

Korpimäki, E., K. Norrdahl, T. Klemola, T. Pettersen, and N. C. Stenseth. 2002. Dynamic effects of predators on cyclic voles: field experimentation and model extrapolation. Proceedings of the Royal Society B 269:991-997.

Korpimäki, E., K. Norrdahl, and J. Valkama. 1994. Reproductive investment under fluctuating predation risk: microtine rodents and small mustelids. Evolutionary Ecology 8: 357-368.

Korpimäki, E., L. Oksanen, T. Oksanen, T. Klemola, K. Norrdahl, and P. B. Banks. 2005. Vole cycles and predation in temperate and boreal zones of Europe. Journal of Animal Ecology 74:1150-1159.
Krebs, C. J. 1995. Two paradigms of population regulation. Wildlife Research 22:1-10.

Krebs, C. J., S. Boutin, R. Boonstra, A. R. E. Sinclair, J. N. M. Smith, M. R. T. Dale, K. Martin, and T. Turkington. 1995. Impact of food and predation on the snowshoe hare cycle. Science 269:1112-1115.

Krebs, C. J., X. Lambin, and J. O. Wolff. 2007. Social behavior and self-regulation in murid rodents. Pages 174-181 in J. O. Wolff and P. W. Sherman, editors. Rodent societies: an ecological and evolutionary perspective. University of Chicago Press, Chicago, Illinois, USA.

Lack, D. 1954. The natural regulation of animal numbers. Clarendon, Oxford, UK.

Lebreton, J.-D., K. P. Burnham, J. Clobet, and D. R. Anderson. 1992. Modeling survival and testing biological hypotheses using marked animals: a unified approach with case studies. Ecological Monographs 62:67-118.

Leroux, S. J., and M. Loreau. 2008. Subsidy hypothesis and strength of trophic cascades across ecosystems. Ecology Letters 11:1147-1156.

Littell, R. C., G. A. Milliken, W. W. Stroup, R. D. Wolfinger, and O. Schabenberger. 2006. SAS for mixed models. Second edition. SAS Institute, Cary, North Carolina, USA.

MacLulich, D. A. 1937. Fluctuations in the numbers of the varying hare (Lepus americanus). University of Toronto Studies, Biology Series No. 43. University of Toronto Press, Toronto, Ontario, Canada.

Meserve, P. L., J. R. Gutierrez, J. A. Yunger, L. C. Contreras, and F. M. Jaksic. 1996. Role of biotic interactions in a small mammal assemblage in semiarid Chile. Ecology 77:114-148.

Meserve, P. L., D. A. Kelt, B. Milstead, and J. R. Gutiérrez. 2003. Thirteen years of shifting top-down and bottom-up control. BioScience 53:633-646.

Michener, G. R. 2004. Hunting techniques and tool use by North American badgers preying on Richardson's ground squirrels. Journal of Mammalogy 85:1019-1027.

Murie, J. O. 1992. Predation by badgers on Columbian ground squirrels. Journal of Mammalogy 73:385-394.

Norrdahl, K. 1995. Population cycles in northern small mammals. Biological Review 70:621-637.

Norrdahl, K., T. Klemola, E. Korpimäki, and M. Koivula. 2002. Strong seasonality may attenuate trophic cascades: vertebrate predator exclusion in boreal grassland. Oikos 99: 419-430.

Norrdahl, K., and E. Korpimäki. 2002. Changes in individual quality during a 3-year population cycle of voles. Oecologia 130:239-249.

Ortega, Y. K., D. E. Pearson, and K. S. McKelvey. 2004. Effects of biological control agents and exotic plant invasion on deer mouse populations. Ecological Applications 14:241253.

Ostfeld, R. S. 1994. The fence effect reconsidered. Oikos 70: $340-348$

Otis, D. L., K. P. Burnham, G. C. White, and D. R. Anderson. 1978. Statistical inference from capture data on closed animal populations. Wildlife Monographs 62. Wildlife Society, Washington, D.C., USA.

Pearson, D. E., and R. M. Callaway. 2006. Biological control agents elevate hantavirus by subsidizing mice. Ecology Letters 9:442-449.

Pearson, D. E., Y. K. Ortega, and L. F. Ruggiero. 2003. Trapinduced mass declines in small mammals: mass as a population index. Journal of Wildlife Management 67:684691.

Pledger, S. 2000. Unified maximum likelihood estimates for closed-recapture models using mixtures. Biometrics 56:434442.

Preisser, E. L., D. I. Bolnick, and M. F. Benard. 2005. Scared to death? The effects of intimidation and consumption in predator-prey interactions. Ecology 86:501-509. 
Previtali, M. A., M. Lima, P. L. Meserve, D. A. Kelt, and J. R. Gutiérrez. 2009. Population dynamics of two sympatric rodents in a variable environment: rainfall, resource availability, and predation. Ecology 90:1996-2006.

Reid, D. G., C. J. Krebs, and A. Kenney. 1995. Limitation of collared lemming population growth at low densities by predation morality. Oikos 73:387-398.

Rosenstock, S. S. 1996. Shrub-grassland small mammal and vegetation responses to rest from grazing. Journal of Range Management 49:199-203.

Royama, T. 1996. A fundamental problem in key factor analysis. Ecology 77:87-93.

SAS. 2008. Version 9.2. SAS, Cary, North Carolina, USA

Soulé, M. E., J. A. Estes, J. Berger, and C. Martinez del Rio. 2003. Ecological effectiveness: conservation goals for interactive species. Conservation Biology 17:1238-1250.

Steen, H., A. Mysterud, and G. Austrheim. 2005. Sheep grazing and rodent populations: evidence of negative interactions from a landscape scale experiment. Population Ecology 143: 357-364.

Stenseth, N. C., and R. A. Ims. 1993. The history of lemming research: from Nordic sagas to the biology of lemmings. Pages 4-34 in N. C. Stenseth and R. A. Ims, editors. The biology of lemmings. Symposium of the Linnean Society. Series 15. Academic Press, London, UK.

Sundell, J. 2006. Experimental tests of the role of predation in the population dynamics of voles and lemmings. Mammal Review 36:107-141.

Turchin, P. 2003. Complex population dynamics: a theoretical/ empirical synthesis. Princeton University Press, Princeton, New Jersey, USA.

White, G. C., and K. P. Burnham. 1999. Program MARK: survival estimation from populations of marked animals. Bird Study 46(Supplement):120-138.

Wolff, J. O. 1996. Population fluctuations of mast-eating rodents are correlated with production of acorns. Journal of Mammalogy 77:850-856.

\section{APPENDIX A}

Predators of the Blackfoot Valley (Ecological Archives E091-261-A1).

\section{APPENDIX B}

Details of predator and/or ungulate exclusion plot construction (Ecological Archives E091-261-A2).

\section{APPENDIX C}

Small-mammal trapping methodology (Ecological Archives E091-261-A3).

\section{APPENDIX D}

General linear model results testing for the effect of treatments on abundance of Spermophilus columbianus, Peromyscus maniculatus, and Microtus montanus (Ecological Archives E091-261-A4).

\section{APPENDIX E}

Survival estimates for Spermophilus columbianus during the experiment (Ecological Archives E091-261-A5). 